\title{
Children Motoric Development Through Variety of Greetings
}

\section{Taat Kurnita Yeniningsih ${ }^{1}$, Nelvi Maulid ${ }^{2}$, Hayati $^{3}$, Aida Fitri ${ }^{4}$, Israwati ${ }^{5}$, Dani Sukma Agus Setiawan ${ }^{6}$ and M. Syukri Azwar Lubis ${ }^{7}$}

\author{
${ }^{1}$ Taat Kurnita Yeniningsih is a Lecturer of Universitas Syiah Kuala, Banda Aceh, \\ Indonesia \\ Email:taatkurnita@unsyiah.ac.id \\ ${ }^{2}$ Nelvi Maulid is a Student of Universitas Syiah Kuala, Banda Aceh, Indonesia \\ Email : nelvimaulida10@gmail.com \\ ${ }^{3}$ Hayati is a Lecturer of Serambi Mekkah University, Banda Aceh, Indonesia \\ Email:hayati@serambimekkah.ac.id \\ ${ }^{4}$ Aida Fitri is a Lecturer of Universitas Syiah Kuala. Banda Aceh, Indonesia \\ Email : aidakesenian13@gmail.com \\ ${ }^{5}$ Israwati is a Lecturer of Universitas Syiah Kuala, Banda Aceh, Indonesia \\ Email : israwati@unsyiah.ac.id \\ ${ }^{6}$ Dani Sukma Agus Setiawan is a Lecturer of Universitas Prima Indonesia, Medan, \\ Indonesia \\ Email : danisukmaagussertiawan@unprimdn.ac.id \\ ${ }^{7}$ M. Syukri Azwar Lubis is Lecturer of Universitas Al Wasliyah, Medan, Indonesia \\ Email : $\underline{\text { msyukriazwarlubis@gmail.com }}$
}

\section{Corresponding author Email : hayati@serambimekkah.ac.id}

\begin{abstract}
Types of greetings are the kinds of movements that result from the greeting process in the form of greetings to someone / another person which will have an impact on the child's motoric skills from the various greeting movements. Variety of greetings is synonymous with the diversity produced by the greeting itself, thus creating gestures similar to greetings. The kinds of greetings referred to are in the form of Assalamu'alaikum, movements of shaking hands, gestures of hugs and clapping movements. The purpose of this study was to determine children's motoric development through the application of various greetings at IT Mon Kuta Kindergarten in Lambhuk Village, Banda Aceh. This is the qualitative research with a descriptive approach. Data collection techniques namely; through interviews and observations. The data analysis technique in this study is a collection of data that has been obtained from the results of children's observations that researchers have done since the beginning of each aspect of research activities, the results that have been collected are entered into the observation sheet. The results showed that the children's motoric development had started well. The motoric development of the child is done through a variety of ways, namely that the child can mimic movements and control movements. So, through various greetings activities can develop children's motoric aspects.
\end{abstract}

Keywords: motoric, early childhood, variety of greetings 
Page : 50-61

\section{INTRUDUCTION}

Early childhood (0-6 years) is a golden period in the development span of an individual, so this period is often referred to as the golden age Diana Kusuma Putri, Tri Joko Raharjo \& Kustiono (2020). At this time, a child experiences extraordinary growth and development, in terms of physical, motoric, emotional, cognitive and psychosocial. Child development takes place in a holistic process in all respects. So, to step into the next developments, the stages of child development, directly or indirectly, will be largely determined by the child's physical and motoric development. Because physical development is sufficient to determine a child's motoric activity, which in turn will affect daily activities and behavior. Children's motoric intelligence will also be influenced by other aspects of development, especially with the physical and intellectual linkages of children (Nurkamelia, 2019: 113).

Children are active creatures, almost all the time that children spend in their lives is in the form of activities. They always move as they want and will stop when they feel tired. The more often the child makes physical movements, the good impact on growth and physical motoric skills. If the growth and physical condition of the child's motoric can develop properly, it will make it easier for children to face preparations for life in the future (Febrialismanto, 2017: 18)

Early childhood education is an effort to stimulate, guide, nurture and provide learning activities that are able to produce children's abilities and skills. Early childhood education is an education that is carried out for children from birth to the age of eight (Module 1 Nest, 2007: 3). The process of education and learning in early childhood should be carried out with the aim of providing meaningful concepts for children through real experiences. Only real experiences allow children to show activity and curiousity optimally and position the educator as a companion, mentor and facilitator for children.

Giving stimulation is a way to help children to develop, children who are stimulated well can achieve aspects of development well too. Stimulus can be given through early childhood education, through education children are given learning through play. Early Childhood Education (PAUD) according to Zastrow (Pujihartati, et al, 2014: 10) is a form of education that focuses on laying the foundation towards physical growth and development (fine and gross motoric coordination), intelligence (thinking power, creativity , emotional intelligence, spiritual intelligence), socio-emotional (attitudes and behavior and religion), language and communication, in accordance with the uniqueness and stages of development that early childhood goes through so that children have readiness to enter further education.

Early Childhood Education (PAUD) is education that is given before children take primary school education. The potential and intelligence possessed by children will develop through the provision of appropriate stimulation at an early age range. So that what is given from an early age will affect children's development at a later stage. Fadlillah (Fitriani: 2018: 26) in Law No. 20 of 2003 Article 1 point 14 states that early childhood education is a coaching effort aimed at children from birth to six years of age which is carried out through providing educational stimuli to assist physical and spiritual growth and development so that children have readiness to enter more education. continue. 
Early childhood development is a gradual change in abilities, emotions, and skills that continues until it reaches a certain age and will be more optimized if the environment in which the child grows and develops supports the child to move freely. Physical development has a very important role in a child's life. Physical development is one of the main developmental tasks in a child's life. Physical development will affect the development and growth of children (Muhammad Usman and Darmawati 2017), The aspects that need to be developed for children in school are motoric, cognitive, emotional, social, morality and personality. According to Sukintaka (Andi Agus Pranowo, 2012: 25) states that Motoric Ability is the quality of the results of individual movements in carrying out motion, both movements that are not sports or movements in sports or the maturity of the appearance of motoric skills. The quality of the results of the movement is the ability (ability) to move a person in carrying out a movement task. "

The focus of this research is early childhood who have entered the pre-school level at TK IT Mon Kuta (4-6 years old). At that age the child experiences changes from the previous stage of life development. One of these changes is the child's motoric development. This development is characterized by better movements performed by children, thus demanding better movements every day. Fitriani (2018: 32) "Giving stimulation for motoric physical development must be done continuously, meaning that it does not stop at just one stimulation, because physical motoric development does not only involve one type of movement and can be directly mastered in one stimulation, but There are many types of movement elements that must be mastered by children in their motoric development".

Motoric development in children is very important to be developed. At the school, there are various activities of greeting as a process of welcoming children. A variety of greetings presents a variety of movements that train children's motoric skills. Thus, researchers are interested in researching children's motoric development through various greetings to see their development.

Children experience development of abilities in line with their physical growth and development. Development of mobility that occurs in kindergarten children is starting to do various kinds of basic movement patterns, which are supported by the development of coordination of the eyes and hands (Samsudin, 2008: 20-21).

To facilitate the child's development process, adequate physical activity is required in various forms of play. The games that are done should be games that can stimulate the development of the large muscles of the child, are simple in nature, provide opportunities for children to do experiments, and develop cooperation with peers (Samsudin, 2008: 21). The most important thing is to provide opportunities for children to do physical activity.

Attitudes that need to be developed at preschool age are imitating movement and controlling movement. The trick is to do a variety of greetings according to the image that has been presented. By playing or doing various motoric greetings activities the child will be better because of the stimulation every day. In addition to developing the motoric

Jurnal Serambi Ilmu 
aspects of the child, these types of greetings can also develop other aspects of development, for example aspects of children's social emotional development. The activities of this variety of greetings have several types of movements, namely in the form of the assalamu'alaikum movement, shaking hands, hugs and claps that are posted on the wall, then choosing one of the images.

When the child chooses one of the various greetings, the teacher will demonstrate it by practicing it with the child as a form of greeting. It is hoped that in this activity, motoric skills in children can be developed. Through this activity, it can train children's movements so that the influence of children's motoric development develops. Based on the above background, the authors are interested in researching with the aim of knowing the emotional motoric of children through the various greetings at TK IT Mon Kuta Banda Aceh.

\section{Motoric Development}

In the early stages of growth, a child will do a lot of movement as a movement activity. Children vent their energy through movement through play activities. Muhibbin (Samsudin, 2008: 11) said that motoric in the language of the term is called "motoric" which is defined as a term that shows things, conditions and activities that have involved the muscles as well as their movements, as well as the glands and their secretions. or sap). In short, motoric can also be understood as any condition that increases or produces stimulation or stimulation of the activities of the physical organs. Movement in early childhood is an activity that never ends and at the same time as a feature of the normal growth and development of children. Movement for early childhood is also a very important part of growth free from interventions that need attention. Meanwhile, Morrison (Harun, 2009: 109) states that movement will also contribute to the intellectual development and skills of children in the next life.

For young children, physical activity and the experiences gained in it are not only beneficial for physical development, the development of the function of body organs, the development of the ability to move, but also for their intellectual development. Before being able to read, write, and count, young children will express their thoughts more through physical activity.

Motoric development is one of the most important factors in the development of the individual as a whole. Basically, motoric development develops in line with the maturity of the nerves and muscles of the child. Thus, every simple movement made by a child is the result of a complex interaction pattern of various parts of the system in the body which is controlled by the brain. Motoric development in children according to Hurlock (Riza, Swaliana 2018: 44) is defined as the development of the maturity elements of controlling body movements and the brain as the center of motion. Meanwhile, according to Slamet Suyanto (Riza, Swaliana 2018: 44) that motoric development is a process of maturity of motion that directly involves the muscles to move and the nervous process that becomes a person capable of moving and the innervation process that enables a person to move his body. From the various opinions above, it can be concluded that motoric development is a change in motoric skills from birth to five years of age that involves various aspects of behavior and motoric skills. 
Brain development will determine the motoric development of children. Motoric development is divided into 2, Sujiono (Nuryanti et al, 2015), namely gross motoric and fine motoric skills. Gross motoric skills are associated with large muscle movements characterized by the child's ability to sit, walk, run, and other activities. Meanwhile, fine motoric skills are related to small muscle movements, such as the child's ability to hold, move things or things, feel something with their lips and mouth, draw, write, and so on. Gross motoric skills are the ability to move the body using large muscles, most or all of the gross motoric body parts are needed so that children can sit, kick, run, go up and down stairs and so on (Depdiknas, 2007: 28). Meanwhile, fine motoric movements are movements that only involve certain body parts which are carried out by small muscles. Therefore, movements in fine motoric skills do not require energy but require careful and thorough coordination (Maya, 2010: 43). According to Aisyah (2008: 37) fine motoric skills are motoric activities that involve the activity of small or fine muscles. This movement requires eye-hand coordination and good movement control that allows them to carry out accuracy and accuracy in motion.

Motoric development in early childhood includes gross and fine motoric skills. Gross motoric skills are body movements that use large muscles or most or all of the body parts that are affected by the maturity of the child himself. Meanwhile, fine motoric skills involve finely regulated movements. Physical development tasks include the ability to sit, kick, run, go up and down stairs as well as coordinate body movements such as running, tiptoeing, jumping, hanging, throwing, catching and maintaining balance. This activity is needed to improve gross motoric coordination skills.

The development of gross motoric movements is related to physical/physical activity using large muscles, such as arm muscles, leg muscles, shoulder muscles, back muscles and abdominal muscles which are influenced by the physical maturity of the child, and in general the movements that can be done children, we can see when the child is playing, the child is playing here and there by running, jumping or playing with the ball. These movements are greatly influenced by the physical and psychological development of the child. Sujiono (Nuryanti et al, 2015: 103) stated that children's motoric development has been divided into two parts, namely gross motoric motion and fine motoric movement. Gross motoric movements are formed when children begin to have coordination and balance almost like adults. Gross motoric movement is an ability that requires most of the coordination of the child's body.

Fine motoric skills are movements that use smooth muscles or certain parts of the body, which are influenced by the opportunity to learn and practice. For example, the ability to move objects from the hand, scribble, arrange blocks, cut, write and so on. Both of these abilities are very important so that children can develop optimally, Santrock (Febrialismanto, 2017: 19). Motoric development is related to the maturity of the muscle mechanism, a condition that provides a progressive appearance in Cratty's motoric skills (Febrialismanto, 2017: 19).

\author{
Jurnal Serambi Ilmu \\ $54 \quad$ Journal of Scientific Information and Educational Creativity
}


Page : 50-61

According to Gallahue (Febrialismanto, 2017: 19) motoric is a biological or mechanical basis that causes motion to occur. In other words, movement is the cumulation of an action which is based on a motoric process. Sumantri (2005: 143) states that fine motoric skills are organizing the use of a group of small muscles such as a child's fingers and hands which often require careful eye-to-hand coordination, skills that include the use of tools for work and small objects or control. against machines such as typing, sewing and others. Meanwhile, according to Woolfolk (2007: 30) states fine motoric skills are: "The earliest period is called the sensorimotoric stage, because the child's thinking involves seeing, hearing, moving, touching, touching and so on". Based on the 2013 curriculum, the indicators of fine motoric development for children aged 4-5 years are to carry out an activity that shows the child is able to use their limbs to perform controlled, smooth movements (for example: shaking hands).

One of the early detection of child development consists of careful monitoring of physical growth and motoric development. Each of these developmental parameters has its own stages according to age development. For example, the motoric development of children aged 6-8 months should be able to crawl and sit. Toddler period is the golden age in the range of a child's development. During the golden age, children experienced extraordinary growth and development, one of which was in terms of their physical and motoric skills. Therefore, the stimulation also needs to take place in a holistic manner.

The motoric development of a child is often different from that of other children. Motoric development at different levels in each individual. Four year olds can easily use scissors while others will probably be after five or six years of age. Some children may be able to jump and catch the ball easily while others may only be able to catch the big ball or roll around. Likewise, environmental stimulation, nutritional status, race and genetics have important influences on motoric development. Certain groups of children are very flexible and interested in gymnastics and regular exercise. They develop better motoric skills. Activities such as wearing clothes, cutting, drawing and writing are easier to do.

Diah Rahmatia (2008: 18) states that the physical development of children is influenced by heredity in the family, gender, nutrition, health, social status, economy, and emotional disorders. It is further explained that the body will directly determine the child's movement skills, and indirectly it will affect the way children see themselves and see others.

According to Bambang Sujiono (2008: 28) states several factors that influence the development of movement skills, namely appearance and environmental factors. It is further explained that appearance factors most often affect certain movement skills, display factors can be in the form of body size, physical growth, strength and weight and the nervous system.

According to Bambang Sujiono (2008: 16) the gross motoric development of children aged 5-6 years, namely: a. Run and kick the ball right away, b. Jumping around with alternating legs, c. Soar a tennis ball with one hand and catch it with both hands, d. Walk on a predetermined line, e. Tiptoe with your hands on your hips, f. Touches toes without bending knees, g. Stroke one leg forwards or backwards without losing balance.

Meanwhile, the characteristics of children in school: a. Kicking the ball, b. Can go down stairs smoothly, c. Tiptoe, d. Walk on the boardwalk, e. Tie your own shoelaces 
f. Throw the ball, g. Catch the ball, h. Zigzag run and i. Stand on one leg for 10 seconds

Table 1.

Level Of Achievement Of Child Development

\begin{tabular}{|c|c|c|}
\hline \multirow{2}{*}{$\begin{array}{c}\text { Scope of } \\
\text { Development }\end{array}$} & \multicolumn{2}{|c|}{ Child Development Achievement Level } \\
\hline & Age 4 - 5 years & Age 5-6 years \\
\hline $\begin{array}{l}\text { Fisik-motoric } \\
\text { A. Rough Motoric }\end{array}$ & $\begin{array}{l}\text { 1. Mimicking animal } \\
\text { movements, trees blowing in } \\
\text { the wind, airplanes, etc. } \\
\text { 2. Doing hanging motion } \\
\text { (hanging) } \\
\text { 3. Perform jumping movements, } \\
\text { 4. Jump, and run in a } \\
\text { coordinated manner } \\
\text { 5. Throwing something directed } \\
\text { 6. Catch something precisely } \\
\text { 7. Make anticipatory movements } \\
\text { 8. Kick something directed } \\
\text { 9. Make use of playing tools } \\
\text { outside the classroom }\end{array}$ & $\begin{array}{l}\text { 1. Perform coordinated body } \\
\text { movements to train } \\
\text { flexibility, balance, and } \\
\text { agility } \\
\text { 2. To coordinate eye-foot- } \\
\text { head movements in } \\
\text { imitating dance or } \\
\text { gymnastics } \\
\text { 3. Doing physical games } \\
\text { with the rules } \\
\text { 4. Skilled in using the right } \\
\text { and left hands } \\
\text { 5. Perform personal hygiene } \\
\text { activities }\end{array}$ \\
\hline B. Fine Motoric & $\begin{array}{l}\text { 1. Make vertical, horizontal, } \\
\text { curved left / right, slanted left / } \\
\text { right, and circles } \\
\text { 2. Tracing the shape } \\
\text { 3. Coordinate the eyes and hands } \\
\text { to perform complex } \\
\text { movements } \\
\text { 4. Perform manipulative } \\
\text { movements to produce a form } \\
\text { using various media } \\
\text { 5. Express yourself with } \\
\text { creating art using various } \\
\text { media } \\
\text { 6. Controlling hand movements } \\
\text { that use smooth muscles } \\
\text { (pinching, stroking, poking, } \\
\text { clenching, twisting, twisting, } \\
\text { squeezing) }\end{array}$ & $\begin{array}{l}\text { 1. Draw according to the } \\
\text { idea } \\
\text { 2. Mimicking the shape } \\
\text { 3. Exploring various media } \\
\text { and activities } \\
\text { 4. Using stationery and } \\
\text { cutlery properly } \\
\text { 5. Cut according to the } \\
\text { pattern } \\
\text { 6. Paste images } \\
\text { appropriately } \\
\text { 7. Express yourself through } \\
\text { detailed drawing } \\
\text { movements }\end{array}$ \\
\hline C. Health and & 1. Weight according to age level & 1. Weight according to age \\
\hline
\end{tabular}




\begin{tabular}{|c|c|c|}
\hline $\begin{array}{l}\text { Behavior } \\
\text { Safety }\end{array}$ & $\begin{array}{l}\text { 2. Height according to age level } \\
\text { 3. Weight according to height } \\
\text { standards } \\
\text { 4. Head circumference according } \\
\text { to age level } \\
\text { 5. Use the toilet (use water, clean } \\
\text { yourself) with minimal } \\
\text { assistance } \\
\text { 6. Understand various hazard } \\
\text { alarms (fire, flood, } \\
\text { earthquake) } \\
\text { 7. Know the traffic signs on the } \\
\text { road }\end{array}$ & $\begin{array}{l}\text { level } \\
\text { 2. Height according to age } \\
\text { standards } \\
\text { 3. Weight according to } \\
\text { height standards } \\
\text { 4. Head circumference } \\
\text { according to age level } \\
\text { 5. Covering the nose and } \\
\text { mouth (for example, } \\
\text { when coughing and } \\
\text { sneezing) } \\
\text { 6. Cleaning and tidying up } \\
\text { the place played } \\
\text { 7. Knowing situations that } \\
\text { endanger yourself } \\
\text { 8. Understand the procedures } \\
\text { for crossing } \\
\text { 9. Know bad habits for } \\
\text { health (cigarettes, liquor) }\end{array}$ \\
\hline
\end{tabular}

(Source: Minister of Education and Culture Regulation, 2014: 22)

\section{Variety of greetings}

Movement of various greetings is a variety of movements resulting from greetings in the form of greetings to someone which will have an impact on individual social interactions. The variety of greetings is something that is identical with the diversity produced by the greeting itself, thus creating several movements that are similar to greetings. The various greetings referred to are in the form of Assalamu'alaikum, movements of shaking hands, movements of hugs and clapping movements.

Through these movements and the opportunities provided by teachers and parents, these movements can stimulate early childhood motoric development, both gross and fine motoric skills. As stated by Piaget (Suyanto, 2005: 119), various studies show that playing provides free space for children, so that children can develop their motoric skills. When playing, children practice adjusting thought and movement into a balance, children are born with reflex abilities, and learn to combine two or more reflex movements, so that children can control their movements and become coordinated movements.

Stimulation in children through a variety of greetings does not only have an effect on motoric development. The variety of greetings also affects the socio-emotional aspects of the child because the child and the teacher play a role when carrying out the various greeting movements. Mena (Liestari, et al, 2005: 2) states "Early childhood educators need to contatly of their role els for children". Mena explained that early childhood education really needs a role relationship, such as parents and teachers in the habit of shaking hands starting from within the family environment. Therefore, various greetings can also develop children's social emotional. 
The steps in carrying out the various greetings activities are neatly lining up and making two lines, one line for boys and one row for girls. Then wait for orders from the teacher to come forward one by one to choose the type of greeting. Then the child must choose a picture of the various greetings that have been provided which is pasted on the wall. After selecting the image, the child makes movements in accordance with the results of the image pointed to by the child. Furthermore, teachers also do the same thing simultaneously with children.

\section{RESEARCH METHODS}

This research is a qualitative research with a descriptive approach. Qualitative research according to Kirk and Miller (Basrowi and Suwandi, 2008: 28) "Qualitative research is a particular tradition in social science which fundamentally relies on observations of humans in their own area and relating to these people in their language and in their terms". The descriptive approach according to Whitney (Tarjo, 2019: 29) states that "Descriptive is finding facts with correct interpretations".

The place where this research was conducted was at TK IT Mon Kuta, which is located at Jln. DR, T. Syarief Thayeb No 5 A Lambhuk Village, Banda Aceh. The subjects in this study were children aged 4-6 years at TK IT Mon Kuta Jln. DR, T. Syarief Thayeb No 5 A Lambhuk Village, Banda Aceh. The data taken were children who had problems with their social emotional development. The subjects were 2 children with the initials Y and R. The object in this study was the social emotional development that occurred in the children of TK IT Mon Kuta Banda Aceh.

Data collection techniques in this study using interview and observation techniques. The data analysis technique was carried out in several steps by researchers in research in the data they obtained with the Miles and Huberman model (Sugiono, 2012: 337), namely: reducing data, presenting data, drawing conclusions.

\section{RESEARCH RESULTS AND DISCUSSION}

From the results of observations made on January 13 and 16 2020, it can be seen in subject $Y$ that he is able to mimic the movements that have been available in the image affixed to the wall. Subject $\mathrm{Y}$ is able to control his movements according to the selected image such as, Assalamu movement, alaikum and tapping motion. Subject $Y$ in his habit often chose the clap motion. He can do the movements properly and correctly. He was very happy to do the various greetings because there were various movements.

From the results of observations made during the variety of greetings on January 13 and 162020 on subject R, it was stated that he was able to do the movements according to his choice. Subject $\mathrm{R}$ includes children whose motoric development is well developed. He is able to mimic the movements found in various greeting activities. Subject $\mathrm{R}$ usually chooses the clapping activity. In this activity he is also able to control his hand movements well according to the picture, for example, shaking hands. 
Page : 50-61

So it can be concluded that the child is able to mimic the movements and control the movements in accordance with the various greetings in the class. This activity involves movements that stimulate motoric development for children.

Activities of various greetings are carried out by teachers and their students so that they generate physical closeness when carrying out the movements that have been provided. These movements are used for motoric development in children. The motoric development of children through various greetings can be seen from the process carried out in various greetings. Regarding the form of child development in IT Mon Kuta Kindergarten, Lambhuk Village Banda Aceh mimics the movements that have been provided in various greetings activities and can control these movements well. Suyanto (2005: 119) says various studies show that playing provides free space for children, so that children can develop their motoric skills. When playing, children practice adjusting thought and movement into a balance, children are born with reflex abilities, and learn to combine two or more reflex movements, so that children can control their movements and become coordinated movements.

During the various greeting activities the children performed their movements with great joy. The children made movements in various greeting activities while smiling at their teacher. The most common thing occurred in the research subjects at TK IT Mon Kuta, Lambhuk Village, Banda Aceh, namely the children were very excited to do these activities before starting the learning process in class. When the child is happy he will do various greetings with joy. Children will train their motoric skills before entering class as a form of initial stimulation through this activity.

\section{CONCLUSION}

Based on the objectives of the research results at IT Mon Kuta Kindergarten, Lambhuk Village, Banda Aceh, it can be concluded that the children's motoric development has started well. Motoric development through various greetings at TK IT Mon Kuta, Lambhuk Village, Banda Aceh, namely mimicking and controlling movements in this activity.

\section{REFERENCES}

- Andi Agus Pranowo. (2012). Kemampuan Motorik Kasar Siswa Kelas IV dan V Sekolah Dasar Negeri 2 Jetis wetan Kecamatan Pedan Kabupaten Klaten.Yogyakarta: Fakultas Ilmu Keolahragaan UNY.

- Aisyah, Siti. 2008. Perkembangan dan Konsep Dasar Pengembangan Anak Usia Dini. Jakarta: Universitas Terbuka

- Bambang Sujiono,dkk. (2008). Metode Pengembangan Fisik. Jakarta : Universitas Terbuka.

- Basrowi dan Suwandi.2008. Memahami Penelitian kualitatif.Jakarta: Rineka Cipta

- Diah Rahmatia. 2008. Bagaimana Pertumbuhan dan Perkembangan Manusia. Bandun: Shakti Adiluhung

- Dpdiknas. 2007. Pedoman Pembelajaran Bidang Pengembangan Fisik/Motorik di Taman Kanak-Kanak. Jakarta: Direktorat Pembinaan Taman Kanak-Kanak 
- Febrialismanto. 2017. Analisis Motoricik Kasar Anak Usia 5-6 Tahun di Taman KanakKanak Kecamatan Bangkinang Kabupaten Kampar. Jurnal EDUCHILD. volume.6:No.1

- Fitriani, Rohyana. 2018. PERKEMBANGAN FISIK MOTORIK ANAK USIA DINI. Jurnal Golden Age Hamzanwadi University. Volume.3:No. 1. (https://www.google.com/search?q=PERKEMBANGAN+FISIK+MOTORICIK+ANA K+USIA+DINI\&oq=PERKEMBANGAN+FISIK+MOTORICIK+ANAK+USIA+DIN $\underline{I}$ \&aqs=chrome..69i57j017.15862j0j8\&sourceid=chrome\&ie=UTF-8)

- Harun, dkk. (2009). Asesmen Perkembangan Anak Usia Dini. Yogyakarta: Multi Pressindo.

- Liestari, dkk. Pembiasaan sikap bersalaman pada anak usia 5-6 tahun di taman kanakkanak. Artikel.( https://www.neliti.com/id/publications/213913/pembiasaan-sikapbersalaman-pada-anak-usia-5-6-tahun-di-taman-kanak-kanak)

- Maya, Hirai. 2010. Melatih Motorik Halus Anak Melalui Origami. Kawan pustaka.com

- Nurkamelia. 2019. Perkembangan Fisik Motorik Anak Usia Dini (Standar Tingkat Pencapaian Perkembangan Anak) STPPA Tercapai di RA Harapan Bangsa Maguwoharjo Condong Catur Yogyakarta. Journal of Islamic Early Childhood $\begin{array}{llll}\text { Education. } & \text { Volume. } & \text { 2:No. } & \text { (http://ejournal.uin- }\end{array}$ suska.ac.id/index.php/KINDERGARTEN)

- Nuryanti, dkk. 2015. Pengembangan Kemampuan Motorik Kasar Anak Melalui Kegiatan Senam Ceria. Jurnal Cakrawala Dini. Vol. 5:No. 2

- Pujihartati, Sri Hilmi, dkk. 2014. Pendidikan Anak Usia DinidiKawasan Pemukiman Kumuh. Surakarta: UPT Penerbitan dan Pencetakan UNS (UNS Press)

- Riza, Muhammad dan Ayu Swaliana. 2018. Deteksi Perkembangan Kompetensi Motorik Anak di PAUD Nadila Kec. Bebesen Kab. Aceh Tengah. Jurnal As-Salam. Volume. 2:No. 3. (https://media.neliti.com/media/publications/293642-deteksiperkembangan-kompetensi-motoricik-97c6afff.pdf)

- Samsudin. (2008). Pembelajaran Motorik Di Taman Kanak-kanak.Jakarta: Prenada Media Group.

- Sugiyono. 2012. Memahami Penelitian Kualitatif. Bandung: Alfabeta

- Sumantri, 2005. Model Pengembangan Keterampilan Motorik Anak Usia Dini. Jakarta: Depdikbud.Suryadi dan Mulyana 2013. Psikologi belajar PAUD. Yogyakarta: Pustaka Insan Madani.

- Suyanto, Slamet. (2005). Dasar-Dasar Pendidikan Anak Usia Dini. Yogyakarta: Hikayat Publishing

- Tarjo. 2019. Metode Penelitian Sistem 3X Baca. Yogyakarta: Deepublish

- Woolfolk, Anita, 2007. Educational Psychology. New York: Boston

- _ 2014. Peraturan Menteri Pendidikan dan Kebudayaan.Jakarta: Depkes 
- Hani Subakti, Eka Selvi Handayani, 2020, Pengembangan Menulis Cerita Pendek Kearifan Lokal Menggunakan Model Mind Mapping Siswa SD Kota Samarinda, Jurnal Serambi Ilmu, 21(2), p. 171-184.

- Diana Kusuma Putri, Tri Joko Raharjo \& Kustiono, 2020. Area group Learning Strategies by Using Brush Away Technique in Identifying Fine Motor and Art Skills for Kindergarden, Journal of Primary Education, 9 (3) (2020) : 299 - 306

- Panggung Sutapa, Suharjana Suharjana 2019. Improving Gross Motor Skills By Gross Kinesthetic-And Contemporary-Based Physical Activity In Early Childhood, Cakrawala Pendidikan, 38(3), p. 540-551

- Muhammad Usman and Darmawati, 2017, Peningkatan Perkembangan AUD, Jurnal Serambi Ilmu, 18(1), Edisi Maret 2017, p. 41-50.

Copyright ( 92021 Taat Kurnita Yeniningsih, Nelvi Maulid, Hayati, Aida Fitri , Israwati , Dani Sukma Agus Setiawan and M. Syukri Azwar Lubis. The manuscript open access article distributed under the Creative Commons Attribution License, which permits unrestricted use, distribution, and reproduction in any medium, provided the original work is properly cited. 